\title{
Analisis Tingkat Kesulitan Belajar Matematika Siswa dalam Menggunakan Prinsip Matematis
}

\author{
Cicik Pramesti ${ }^{1}$, Ariesandi Prasetya ${ }^{2}$ \\ 1,2Program Studi Pendidikan Matematika, Universitas PGRI Adi Buana Kampus Blitar \\ E-mail: cicik_stkipblt@yahoo.com ${ }^{1}$, ariessandi35@yahoo.co.id ${ }^{2}$
}

\begin{abstract}
Abstrak
Di dunia pendidikan masih ditemukan siswa mengalami kesulitan belajar matematika. Kesulitan belajar matematika merupakan suatu kondisi, seseorang tidak mampu belajar matematika dengan baik terkait dalam menyebutkan hal-hal yang diketahui dan yang ditanyakan, kalkulasi, serta penerapan rumus. Berdasarkan keadaan tersebut peneliti melakukan penelitian yang bertujuan untuk menganalisis kesulitan belajar matematika dalam menggunakan prinsip matematis pada materi determinan dan invers matriks. Kesulitan tersebut dianalisis berdasarkan indicator kesulitan belajar matematika dalam menggunakan prinsip matematis (1) kesalahan perhitungan atau operasi aljabar, (2) tidak mampu menentukan data yang relevan, dan (3) tidak dapat menerapkan rumus. Jenis penelitian adalah deskriptif kualitatif, dengan instrumennya tes dan wawancara. Deskripsi hasil analisis kesulitan belajar matematika dalam menggunakan prinsip matematis adalah pada indikator: (1) kesalahan penghitungan masih berada pada kriteria tingkat tinggi, sehingga kemampuan berhitung masih perlu ditingkatkan kembali khususnya dalam hal ketelitian, kecermatan, serta kehati-hatian; (2) ketidakmampuan menentukan data yang relevan berada pada kriteria tingkat sedang, namun kemampuan ini masih dapat ditingkatkan kembali dengan cara pembiasaan menuliskan hal-hal yang diketahui dan yang ditanyakan untuk mempermudah menyelesaikan permasalahan; dan (3) tidak dapat menerapkan rumus berada pada kriteria tingkat rendah, yang didominasi oleh siswa berkemampuan rendah. Kesulitan ini dapat diminimalkan dengan cara pembimbingan langsung oleh guru dan atau melalui tutor sebaya.
\end{abstract}

Kata Kunci: analisis, kesulitan belajar matematika, prinsip matematis

\section{Analysis of Students' Mathematics Learning Difficulty Levels in Using Mathematical Principles}

\begin{abstract}
In the world of education there are still many students who have difficulty learning mathematics. Difficulty learning mathematics is a condition, a person is not able to learn mathematics well. The difficulty in learning mathematics is related in mentioning things that are known and asked for, calculating (counting), and application of formulas. Based on these circumstances, the researcher conducted a study that aims to analyze the difficulties of learning mathematics in using the principles of determinant and inverse matrix material. This learning difficulty was analyzed based on indicators of learning difficulties in mathematics using the principles of (1) calculation errors or algebraic operations, (2) unable to determine relevant data, and (3) unable to apply formulas. This type of research is descriptive qualitative, with the research instruments are tests and interviews. The descriptions of the results of the analysis of the difficulty of learning mathematics in using the principles are: (1) the calculation error indicator is still at a high level criterion, so that the students' numeracy skills still need to be improved, especially in terms of accuracy, accuracy, and caution; (2) the inability to determine relevant data is at the medium level criteria, but this ability can still be improved again by getting used to writing things that are known and asked for to make it easier to solve mathematical problems; and (3) the indicators of not being able to apply the formula are at low level criteria, which are dominated by low-ability students. This difficulty can be minimized by direct mentoring by the teacher and or through peer tutors.
\end{abstract}

Keywords: analysis, mathematics learning difficulty, mathematical principles 


\section{PENDAHULUAN}

Belajar merupakan suatu proses yang dilakukan oleh seorang individu untuk memperoleh kapabilitas, baik dalam ranah kognitif, afektif maupun psikomotorik. Ketiga kemampuan tersebut selanjutnya akan mengubah pola fikir, sikap perilaku, serta keterampilan seseorang yang telah melakukan suatu kegiatan yang disebut belajar. Hal ini sesuai dengan yang disampaikan (Dangnga \& Muis, 2015) belajar merupakan proses yang dilakukan oleh seseorang untuk mencapai berbagai macam kompetensi, keterampilan, dan sikap. Sehingga seseorang dapat dikatakan belajar apabila sudah mengalami perubahan dan atau perbaikan baik dari pengetahuan/cara berpikir, sikap perilaku, keterampilan berpikir serta keterampilan dalam menyelesaikan suatu permasalahan. Belajar sangat penting bagi setiap individu agar cara berpikir, sikap perilaku, maupun keterampilan seseorang dapat berkembang menjadi lebih baik. Seseorang dapat belajar dimanapun mereka berada, baik di sekolah formal, sekolah non formal, bahkan belajar melalui pengalaman. Belajar di sekolah formal harus mengikuti kurikulum yang digunakan di suatu negara. Di Indonesia sesuai kurikulumnya pada jenjang sekolah dasar hingga menengah, pebelajar wajib mempelajari matematika.

Matematika merupakan ilmu yang sarat dengan materi-materi yang memerlukan pemikiran/penalaran logis dan sistematis (Pramesti, 2019). Sedangkan menurut (Hasratuddin, 2014) "matematika adalah suatu cara untuk menemukan jawaban terhadap masalah yang dihadapi manusia; suatu cara menggunakan informasi, menggunakan pengetahuan tentang bentuk dan ukuran, menggunakan pengetahuan tentang menghitung, dan yang paling penting adalah memikirkan dalam diri melihat dan menggunakan hubungan-hubungan". Sehingga jika kemampuan seseorang dalam belajar matematika baik, maka seseorang tersebut akan mampu berpikir secara logis dan sistematis, mampu menghitung dengan baik, serta mampu menyelesaikan masalah dengan beberapa kemungkinan. Namun pada kenyataannya dalam mempelajari matematika, masih ditemukan pebelajar yang mengalami kesulitan.

Kesulitan belajar merupakan suatu kondisi seseorang tidak mampu belajar dengan baik. Ketidakmampuan seseorang ini disebabkan adanya gangguan. Gangguan tersebut dapat berasal dari dalam diri seseorang (intern) ataupun dari luar (ekstern). Faktor intern ini dibatasi oleh faktor inteligensi seseorang, sedangkan faktorn ekstern berasal dari lingkungan seseorang tersebut (lingkungan keluarga, tempat belajar, dan sebagainya). Hal tersebut diperkuat oleh pendapat Van Steenbrugge (Kusumaningrum et al., 2019) yang menyatakan bahwa kesulitan belajar dapat dibedakan menjadi dua jenis, yaitu: ketidakmampuan belajar yang terletak dalam perkembangan kognitif peserta didik sendiri dan kesulitan belajar yang disebabkan oleh faktor di luar peserta didik atau masalah lainnya. Selanjutnya kesulitan belajar inilah yang dapat mengakibatkan rendahnya prestasi belajar siswa (Hasibuan, 2018). Hal ini harus diperhatikan dan dicarikan solusinya sebab apabila dibiarkan berkelanjutan akan menjadi ancaman terhadap masa depan bangsa, mengingat jika banyak siswa yang mengalami kesulitan belajar maka prestasi belajar siswa juga akan semakin rendah.

Matematika merupakan ilmu yang penting namun pada kenyataannya pelajaran matematika kurang diminati, ditakuti, dan membosankan bagi siswa, (Surya \& Novriani, 2017). Akibatnya terdapat beberapa siswa yang mengalami kesulitan belajar matematika. Siswa yang mengalami kesulitan dalam pembelajaran matematika dan cepat bosan adalah siswa-siswa yang memiliki persepsi negatif (Syarifah \& Richanatus, 2017). Kesulitan belajar matematika disebut juga dyscalculia. Istilah diskalkulia memiliki konotasi medis, yang memandang adanya keterkaitan dengan gangguan sistem saraf pusat. Secara medis diskalkulia diartikan sebagai gangguan pada kemampuan kalkulasi secara sistematis, yang dibagi menjadi bentuk kesulitan berhitung dan kesulitan kalkulasi. "Children with dyscalculia are delayed in beginning to finger count, are slow to discover that finger counting may be used for calculation, and persist in finger counting for longer" (Fritz et al., 2019). Artinya anak-anak yang mengalami diskalkulia biasanya juga tidak memahami proses matematis, yang ditandai dengan kesulitan mengerjakan tugas yang melibatkan angka atau simbol matematis. Sehingga kesulitan belajar matematika itu berkaitan dengan menjelaskan konsep, menyebutkan contoh dan bukan contoh, pemahaman konsep, penggunaan simbol, kalkulasi (berhitung), penerapan konsep, serta pemahaman soal cerita. 
Menurut Cooney (Yusmin, 2017) menyatakan bahwa kesulitan belajar matematika siswa diklasifikasikan ke dalam tiga jenis kesulitan dengan kriteria sebagai berikut: (1) kesulitan siswa dalam menggunakan konsep matematis, yakni: ketidakmampuan untuk mengingat nama-nama secara teknis, ketidakmampuan untuk menyatakan arti dari istilah yang mewakili konsep tertentu, ketidakmampuan untuk mengingat satu atau lebih kondisi yang diperlukan bagi suatu objek untuk dinyatakan dengan istilah yang mewakilinya, ketidakmampuan untuk mengingat suatu kondisi yang cukup bagi suatu objek untuk dinyatakan dengan istilah yang mewakili konsep tersebut, tidak dapat mengelompokkan objek sebagai contoh-contoh suatu konsep dari objek yang bukan contohnya, serta ketidakmampuan untuk menyimpulkan informasi dari suatu konsep yang diberikan; (2) kesulitan siswa dalam menggunakan prinsip matematis, yakni: tidak mampu melakukan kegiatan penemuan tentang sesuatu yang tidak teliti dalam perhitungan atau operasi aljabar, ketidakmampuan siswa untuk menentukan faktor yang relevan dan akibatnya tidak mampu mengabstraksikan pola-pola, serta siswa dapat menyatakan suatu prinsip tetapi tidak dapat mengutarakan artinya, dan tidak dapat menerapkan prinsip tersebut; dan (3) kesulitan siswa dalam menyelesaikan masalah verbal, yang berarti bahwa kemampuan siswa dalam menyelesaikan masalah verbal sangat ditentukan oleh pengetahuan dan kemampuan siswa dalam menggunakan konsep-konsep dan prinsip-prinsip. Apabila seorang siswa tidak memahami istilah-istilah khusus, dan mengalami ketidakmampuan seperti yang dipaparkan, maka siswa tersebut tentu akan mengalami kesulitan dalam menyelesaikan masalah-masalah verbal.

Selanjutnya penelitian ini difokuskan pada kesulitan belajar matematika dalam menggunakan prinsip menurut Cooney. Mengadop Cooney (Yusmin, 2017), maka indikator kesulitan belajar matematika dalam menggunakan prinsip matematis adalah (1) kesalahan perhitungan atau operasi aljabar, (2) tidak mampu menentukan data yang relevan, dan (3) tidak dapat menerapkan rumus. Sehingga tujuan penelitian ini adalah untuk menganalisis kesulitan belajar matematika dalam menggunakan prinsip matematis. Mengingat seorang pendidik harus mengetahui kesulitan belajar khususnya matematika yang dialami oleh siswa agar pendidik dapat memperbaiki proses pembelajarannya di dalam kelas (Jamal, 2014).

\section{METODE}

Penelitian ini menganalisis kesulitan belajar matematika dalam menggunakan prinsip dengan instrumen tes dan wawancara. Jenis penelitian ini adalah deskriptif kualitatif sebab hasil analisisnya akan dideskripsikan. Sesuai dengan tujuan penelitian deskriptif yakni untuk membuat pecandraan secara sistematis, faktual, dan akurat mengenai fakta-fakta dan sifat-sifat populasi atau daerah tertentu, (Suryabrata, 2013).

Subyek penelitian ini adalah 9 siswa kelas X AKL 1 di SMKN 1 Nglegok tahun pelajaran 2018/2019 yang terdiri dari 3 siswa kemampuan rendah, 3 siswa kemampuan sedang, dan 3 siswa kemampuan tinggi. Pemilihan subyek penelitian berdasarkan tingkat kemampuan siswa (rendah, sedang, dan tinggi) yang diperoleh dari nilai matematika semester ganjil.

Pengambilan data tes dan wawancara dilaksanakan secara bersamaan, yakni setiap siswa diminta untuk mengerjakan tes dan dilanjutkan dengan wawancara terkait dengan penyelesaian tes determinan dan invers matriks. Hal ini dilakukan agar data yang diperoleh valid. Analisis data dilakukan melalui tiga tahapan yaitu reduksi data, penyajian data, dan penarikan kesimpulan.

\section{HASIL DAN PEMBAHASAN}

Data hasil penelitian ini dipaparkan menjadi dua tahap, yakni 1) tahap pra penelitian dan 2) tahap pelaksanaan penelitian. Tahap pra penelitian, peneliti menentukan populasi dan sampel. Populasinya adalah siswa SMKN 1 Nglegok Blitar tahun pelajaran 2018/2019, sedangkan sampelnya adalah siswa kelas X AKL 1. Setelah memperoleh sampel, langkah selanjutnya adalah menentukan subyek penelitian. Mula-mula peneliti menganalisis nilai matematika semester 1 siswa kelas X AKL 1 dan mengelompokkan sesuai dengan tingkat kemampuan siswa (tinggi, sedang, dan rendah). Setelah itu peneliti memilih secara acak, dari setiap kelompok tingkat kemampuan siswa, masing-masing dipilih 3 siswa. Sehingga subyek penelitian berjumlah 9 siswa. 
Tabel 1. Hasil Analisis Data Kesulitan Belajar Matematika Siswa dalam Menggunakan Prinsip Berdasarkan Data Hasil Tes

\begin{tabular}{|c|c|c|c|c|}
\hline \multirow{2}{*}{$\begin{array}{c}\text { Nomor } \\
\text { Soal } \\
\text { Tes }\end{array}$} & \multirow[b]{2}{*}{$\begin{array}{c}\text { Subyek } \\
\text { Penelitian }\end{array}$} & \multicolumn{3}{|c|}{$\begin{array}{c}\text { Indikator Jenis Kesulitan Belajar Matematika Siswa Dalam } \\
\text { Menggunakan Prinsip }\end{array}$} \\
\hline & & $\begin{array}{c}\text { Kesalahan } \\
\text { Perhitungan }\end{array}$ & $\begin{array}{l}\text { Tidak Mampu } \\
\text { Menentukan Data } \\
\text { Yang Relevan }\end{array}$ & $\begin{array}{l}\text { Tidak Dapat } \\
\text { Menerapkan } \\
\text { Rumus }\end{array}$ \\
\hline \multirow{9}{*}{1} & S1 & - & - & - \\
\hline & S2 & $\sqrt{ }$ & - & - \\
\hline & S3 & - & - & - \\
\hline & S4 & - & $\sqrt{ }$ & - \\
\hline & S5 & - & - & - \\
\hline & S6 & - & $\sqrt{ }$ & - \\
\hline & S7 & $\sqrt{ }$ & $\sqrt{ }$ & - \\
\hline & S8 & - & $\sqrt{ }$ & - \\
\hline & S9 & $\sqrt{ }$ & $\sqrt{ }$ & $\sqrt{ }$ \\
\hline \multirow{9}{*}{2} & S1 & - & - & - \\
\hline & S2 & $\sqrt{ }$ & - & - \\
\hline & S3 & - & - & - \\
\hline & S4 & $\sqrt{ }$ & - & - \\
\hline & S5 & - & $\sqrt{ }$ & - \\
\hline & S6 & $\sqrt{ }$ & - & - \\
\hline & S7 & $\sqrt{ }$ & - & - \\
\hline & S8 & $\sqrt{ }$ & $\sqrt{ }$ & $\sqrt{ }$ \\
\hline & S9 & $\sqrt{ }$ & - & $\sqrt{ }$ \\
\hline \multirow{9}{*}{3} & S1 & $\sqrt{ }$ & - & $\sqrt{ }$ \\
\hline & S2 & - & - & - \\
\hline & S3 & $\sqrt{ }$ & - & - \\
\hline & S4 & $\sqrt{ }$ & - & $\sqrt{ }$ \\
\hline & S5 & $\sqrt{ }$ & - & - \\
\hline & S6 & $\sqrt{ }$ & $\sqrt{ }$ & - \\
\hline & S7 & - & $\sqrt{ }$ & - \\
\hline & S8 & $\sqrt{ }$ & - & - \\
\hline & S9 & $\sqrt{ }$ & - & - \\
\hline \multirow{9}{*}{4} & S1 & - & - & $\sqrt{ }$ \\
\hline & S2 & - & - & - \\
\hline & S3 & - & - & - \\
\hline & S4 & - & - & - \\
\hline & S5 & - & - & - \\
\hline & S6 & $\sqrt{ }$ & $\sqrt{ }$ & - \\
\hline & S7 & - & - & - \\
\hline & S8 & - & - & - \\
\hline & S9 & $\sqrt{ }$ & - & $\sqrt{ }$ \\
\hline
\end{tabular}

Tahap pelaksanaan penelitian, peneliti melakukan pengambilan data dengan beberapa langkah, yakni: 1) melaksanakan tes determinan dan invers matriks, 2) melaksanakan wawancara, dan 3) menganalisis data hasil tes dan wawancara. Tes dan wawancara ini dilakukan untuk mengetahui kesulitan belajar matematika siswa dalam menggunakan prinsip. Tes yang digunakan berupa soal uraian sebanyak 4 soal yang terdiri dari 2 soal determinan dan 2 soal invers matriks. Sedangkan wawancara dilakukan untuk memperkuat data hasil tes. Tes diberikan kepada 9 siswa untuk dikerjakan. Setelah kesembilan siswa selesai mengerjakan tes, maka tes dikoreksi dan dianalisis oleh peneliti terkait dengan kesulitan belajar matematika siswa dalam menggunakan prinsip. Adapun hasil 
analisis kesulitan belajar matematika siswa dalam menggunakan prinsip berdasarkan data hasil tes dapat dilihat pada tabel 1 .

Pada tabel 1 dapat diketahui bahwa pada soal nomor satu, 3 dari 9 siswa mengalami kesulitan perhitungan, 5 dari 9 siswa mengalami kesulitan dalam menentukan data yang relevan, serta 1 dari 9 siswa mengalami kesulitan dalam menerapkan rumus. Pada soal nomor dua diketahui bahwa 6 dari 9 siswa mengalami kesulitan perhitungan, 2 dari 9 siswa mengalami kesulitan dalam menentukan data yang relevan, serta 2 dari 9 siswa mengalami kesulitan dalam menerapkan rumus. Pada soal nomor tiga diketahui bahwa 7 dari 9 siswa mengalami kesulitan perhitungan, 7 dari 9 siswa mengalami kesulitan dalam menentukan data yang relevan, serta 1 dari 9 siswa mengalami kesulitan dalam menerapkan rumus. Sedangkan pada soal nomor empat diketahui bahwa 2 dari 9 siswa mengalami kesulitan perhitungan, 1 dari 9 siswa mengalami kesulitan dalam menentukan data yang relevan, serta 1 dari 9 siswa mengalami kesulitan dalam menerapkan rumus. Keadaan tersebut dapat dilihat pada gambar 1.

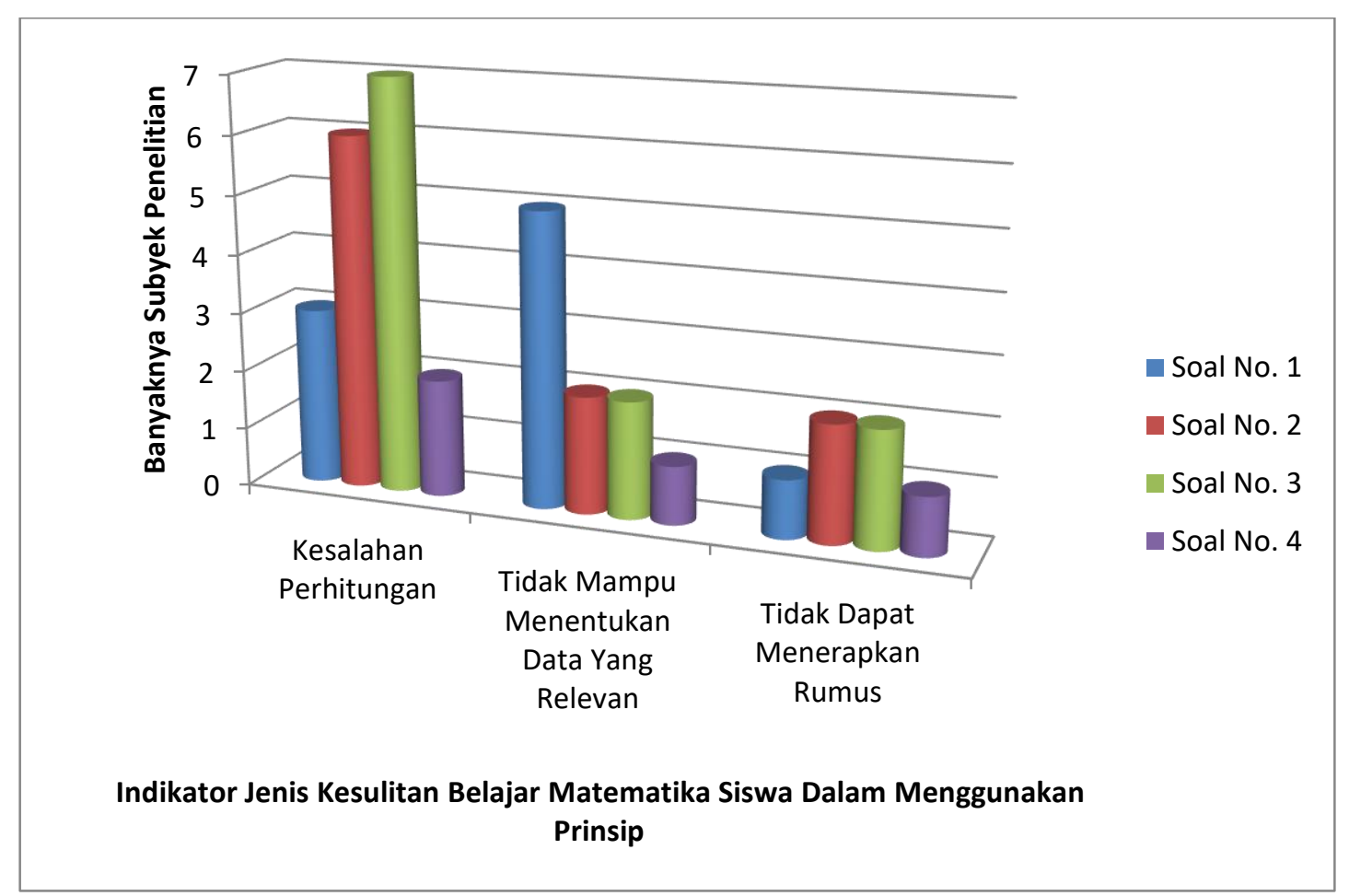

Gambar 1. Diagram Hasil Analisis Kesulitan Belajar Matematika Siswa Dalam Menggunakan Prinsip Berdasarkan Data Hasil Tes

Pada gambar 1 dapat diketahui bahwa mayoritas siswa mengalami kesulitan berhitung, karena masih ditemukan 7 dari 9 siswa yang mengalami kesulitan belajar matematika dalam menggunakan prinsip indikator kesalahan perhitungan. Pada jenis kesulitan belajar matematika dalam menggunakan prinsip indikator ketidakmampuan menentukan data yang relevan ini sebagian siswa juga masih mengalami kesulitan, karena masih ditemukan sebanyak 5 dari 9 siswa yang mengalami kesulitan. Sedangkan untuk kesulitan belajar matematika dalam menggunakan prinsip indikator tidak dapat menerapkan rumus hanya ditemukan 2 dari 9 siswa yang mengalami kesulitan.

Selain tes peneliti juga menganalisis data hasil wawancara. Wawancara yang dilakukan ini untuk menguatkan hasil analisis data tes. Hasil wawancara yang dilakukan kepada semua subyek penelitian, dapat disimpulkan bahwa mayoritas siswa menyatakan bahwa tidak mengalami kesulitan dalam mempelajari determinan dan matriks. Mayoritas siswa menyampaikan bahwa penyebab siswa mengalami kesulitan belajar matematika dalam menggunakan prinsip indikator kesalahan penghitungan dan ketidakmampuan menentukan data yang relevan adalah kurangnya ketelitian siswa. Namun terdapat 1 siswa yang menyatakan bahwa selalu mengalami kesulitan jika menghitung terkait dengan bilangan yang mengandung tanda negatif. Sedangkan kesulitan belajar matematika dalam 
menggunakan prinsip indikator tidak dapat menerapkan rumus yang telah dialami sebagian siswa disebabkan oleh adanya faktor lupa dengan rumus yang seharusnya digunakan dan juga kurang memahami soal yang diberikan.

Selanjutnya untuk kriteria tingkat kesulitan belajar matematika siswa dalam menggunakan prinsip yang telah dialami siswa dapat dilihat pada tabel 2 .

Tabel 2. Kriteria Tingkat Kesulitan Belajar Matematika Siswa Dalam Menggunakan Prinsip

\begin{tabular}{lcc}
$\begin{array}{c}\text { Indikator Jenis Kesulitan } \\
\text { Belajar Matematika Siswa } \\
\text { Dalam Menngunakan } \\
\text { Prinsip }\end{array}$ & $\begin{array}{c}\text { Interval Siswa } \\
\text { Yang } \\
\text { Mengalami } \\
\text { Kesulitan }\end{array}$ & $\begin{array}{c}\text { Kriteria Tingkat Kesulitan Belajar } \\
\text { Matematika Siswa Dalam } \\
\text { Menngunakan Prinsip }\end{array}$ \\
\hline Kesalahan Penghitungan & 0 siswa & Tidak Mengalami Kesulitan \\
\hline $\begin{array}{l}\text { Tidak Mampu Menentukan } \\
\text { Data Yang Relevan }\end{array}$ & $\begin{array}{c}1-3 \text { siswa } \\
4-6 \text { siswa }\end{array}$ & $\begin{array}{c}\text { Tingkat Rendah } \\
\text { Tingkat Sedang }\end{array}$ \\
\hline $\begin{array}{l}\text { Tidak Dapat Menerapkan } \\
\text { Rumus }\end{array}$ & $7-9$ siswa & Tingkat Tinggi \\
\hline
\end{tabular}

Berdasarkan tabel 2 tersebut dapat dikatakan bahwa kriteria kesulitan belajar matematika siswa dalam menggunakan prinsip indikator kesalahan penghitungan berada pada tingkat tinggi. Kriteria kesulitan belajar matematika siswa dalam menggunakan prinsip indikator ketidakmampuan menentukan data relevan berada pada tingkat sedang. Sedangkan kriteria kesulitan belajar matematika siswa dalam menggunakan prinsip indikator tidak dapat menerapkan rumus berada pada tingkat rendah.

\section{Kesulitan Belajar Matematika Siswa dalam Menggunakan Prinsip Indikator Kesalahan Penghitungan}

Kriteria kesulitan belajar matematika siswa dalam menggunakan prinsip indikator kesalahan penghitungan berada pada tingkat tinggi. Hal ini berarti mayoritas siswa mengalami kesulitan dalam hal kesalahan penghitungan. Padahal belajar berhitung sudah dikenalkan kepada siswa sejak masih berada di lingkungan keluarga, belum masuk di lingkungan pendidikan formal. Sehingga seharusnya siswa sudah sangat lancar melakukan kegiatan belajar yang disebut berhitung. Berasal dari sebab inilah siswa masih mengalami kesulitan dalam hal berhitung. Seringkali siswa menganggap bahwa berhitung adalah hal yang mudah, sehingga seringkali "meremehkan". Padahal pada proses berhitung diperlukan ketelitian kecermatan, serta kehati-hatian dalam menyelesaikannya (Pramesti, 2019). Hal ini diperkuat dari hasil wawancara kepada siswa bahwa kesalahan dalam berhitung yang dilakukan disebabkan karena siswa kurang teliti dan terburu-buru dalam prosesnya.

Jika demikian yang terjadi, ini berarti siswa sebenarnya mempunyai kemampuan dalam berhitung yang baik, hanya saja masih perlu ditingkatkan dalam hal ketelitian, kecermatan serta kehati-hatiannya dalam melakukan proses berhitung. Kesulitan berhitung yang dialami siswa ini harus menjadi perhatian pendidik, sebab apabila siswa melakukan kesalahan berhitung dari awal menyelesaikan permasalahan maka itu akan sangat mempengaruhi hasil akhir. Artinya kesalahan tersebut dapat berakibat fatal pada proses penyelesaian suatu permasalahan matematika yang diberikan. Padahal siswa memahami konsep materi matematika yang sedang diujikan, namun apabila kesalahan penghitungan terjadi, maka kemampuan pemahaman konsepnya akan menjadi sia-sia. Seperti yang diungkapkan Jamaris yang menyatakan bahwa banyak siswa yang mempunyai pemahaman konsep matematika yang baik, namun kurang dalam berhitung (Pramesti, 2019).

Namun demikian tidak menutup keungkinan bahwa kesulitan berhitung yang dialami oleh siswa karena kurangnya kemampuan siswa dalam berhitung, seperti yang disampaikan siswa pada saat wawancara. Siswa menyebutkan bahwa siswa memang sering mengalami kesulitan berhitung khususnya jika terkait dengan bilangan negatif. Hal ini sejalan dengan hasil penelitian (Sidik \& Wakih, 2020) yang menyatakan bahwa siswa kesulitan mengoperasikan bilangan yang memuat tanda negatif dan melakukan operasi hitung pembagian.

Berdasarkan deskripsi tersebut dapat diketahui bahwa kesulitan belajar matematika siswa dalam menggunakan prinsip indikator kesalahan perhitungan masih berada pada tingkat tinggi. Berarti untuk 
kemampuan berhitung siswa, masih perlu ditingkatkan kembali, khususnya dalam hal ketelitian, kecermatan, serta kehati-hatian dalam proses perhitungan.

\section{Kesulitan Belajar Matematika Siswa Dalam Menggunakan Prinsip Indikator Ketidakmampuan Menentukan Data Yang Relevan}

Kriteria kesulitan belajar matematika siswa dalam menggunakan prinsip indikator ketidakmampuan menentukan data yang relevan berada pada tingkat sedang. Ini menunjukkan bahwa tidak kurang dari setengah subyek penelitian mengalami kesulitan tersebut. Padahal pada kemampuan dalam menentukan data yang relevan ini akan menunjukkan pemahaman siswa terhadap permasalahan yang diberikan. Selain itu data yang relevan tersebut selanjutnya digunakan siswa untuk menyelesaikan permasalahan yang dihadapi.

Dewasa ini memang sering ditemui siswa menyelesaikan permasalahan menggunakan cara cepat. Kebiasaan ini yang menyebabkan siswa terlena dalam menyelesaikan permasalahan. Setelah siswa diminta untuk menyelesaikan permasalahan secara sistematis (step by step), siswa sering melupakan hal-hal yang seharusnya dituliskan terlebih dahulu, karena kebiasaan menggunakan cara cepat. Akhirnya mengarahkan siswa kepada keadaan yang disebut kurang teliti, kurang cermat, serta kurang hati-hati dalam menyeleaikan permasalahan. Siswa cenderung ingin cepat menyelesaikan permasalahan yang diberikan.

Menentukan data yang relevan pada saat menyelesaikan permasalahan sangat diperlukan guna memudahkan siswa dalam menyelesaikan permasalahan, serta dapat mengurangi kesalahan. Dengan menentukan data yang relevan dan menuliskannya, maka siswa tidak perlu lagi membaca permasalahan karena lupa apa yang telah diketahui dan ditanyakan pada permasalahan tersebut. Selain itu kemampuan dalam menentukan data yang relevan dapat menunjukkan pemahaman siswa terhadap permasalahan yang diberikan, seperti yang diungkapkan oleh Sudarman yang menyatakan bahwa siswa dikatakan memahami permasalahan jika mampu mengungkapkan data yang diketahui dan ditanyakan dari masalah yang diberikan (Hapizah, 2017).

Berdasarkan deskripsi tersebut dapat diketahui bahwa kesulitan belajar matematika siswa dalam menggunakan prinsip indikator tidak mampu menentukan data yang relevan berada pada kriteria tingkat sedang. Berarti untuk kemampuan siswa dalam menentukan data yang relevan, masih perlu ditingkatkan kembali dengan cara pembiasaan. Artinya siswa kembali dibiasakan untuk menentukan data yang relevan dan menuliskannya untuk mempermudah menyelesaikan permasalahan matematika yang diberikan.

\section{Kesulitan Belajar Matematika Siswa Dalam Menggunakan Prinsip Indikator Tidak Dapat Menerapkan Rumus}

Kriteria kesulitan belajar matematika siswa dalam menggunakan prinsip indikator tidak dapat menerapkan rumus berada pada tingkat rendah. Data menyatakan bahwa kesulitan dialami karena siswa lupa dengan rumus yang seharusnya digunakan untuk menyelesaikan permasalahan yang dihadapi. Jika terjadi lupa berarti siswa melakukan suatu kegiatan yang disebut menghafal. Padahal dalam belajar sebaiknya dilakukan proses meaningful learning. Artinya siswa tidak mengahafalkan rumus, namun memahami bagaimana rumus itu berasal. Sehingga apabila siswa menemukan suatu permasalahan siswa dapat menggunakan rumus matematika yang tepat.

Lupa terhadap suatu rumus, dapat diartikan kurang memahami materinya. Hal ini berbanding lurus dengan kemampuan matematika siswa. Pada data yang diperoleh diketahui bahwa siswa yang mengalami kesulitan dalam menerapkan rumus tersebut adalah siswa dengan kemampuan rendah. Hal ini senada dengan hasil penelitian (Apriliawan et al., 2013) yang menyatakan bahwa siswa dengan kemampuan matematika rendah cenderung melakukan kesalahan dalam menyelesaikan soal. Kesalahan yang dilakukan dapat berasal dari kesalahan dalam perhitungan, menentukan data yang relevan, maupun menerapkan rumus yag sesuai.

Berdasarkan deskripsi tersebut dapat diketahui bahwa kesulitan belajar matematika siswa dalam menggunakan prinsip indikator tidak dapat menerapkan rumus berada pada kriteria tingkat rendah. Siswa yang mengalami kesulitan tersebut ditemukan siswa dengan kemampuan rendah. Berarti masih diperlukan pembimbingan yang lebih serius kepada siswa yang berkemampuan rendah. 
Pembimbingan tersebut tidak harus langsung oleh guru, namun dapat dilakukan dengan cara tutor sebaya. Sehingga siswa yang berkemampuan rendah dapat ditingkatkan kemampuannya. Namun demikian peran guru tetap diperlukan untuk mengatasi kesulitan belajar matematika siswa. Seperti yang diungkapkan (Ardi et al., 2019) yang menyatakan bahwa perhatian penuh terhadap risiko kesulitan belajar perlu dilakukan oleh guru agar dapat mengoptimalkan proses pembelajaran di sekolah dengan tetap memperhatikan ritme, dan perbedaan individu dalam pembelajaran. Hal tersebut berarti perlu adanya komunikasi antara guru dan siswa untuk membantu menganalisis materi matematika (mengalami kesulitan) secara tatap muka (Wang et al., 2009).

\section{SIMPULAN}

Berdasarkan deskripsi hasil analisis terhadap hasil tes dan wawancara diperoleh suatu kesimpulan bahwa kesulitan belajar matematika siswa dalam menggunakan prinsip indikator kesalahan perhitungan masih berada pada tingkat tinggi. Berarti untuk kemampuan berhitung siswa, masih perlu ditingkatkan kembali khususnya dalam hal ketelitian, kecermatan, serta kehati-hatian dalam proses penghitungan. Kesulitan belajar matematika siswa dalam menggunakan prinsip indikator tidak mampu menentukan data yang relevan berada pada tingkat sedang. Berarti untuk kemampuan siswa dalam menentukan data yang relevan, masih perlu ditingkatkan kembali dengan cara pembiasaan untuk menentukan data yang relevan dan menuliskannya untuk mempermudah menyelesaikan permasalahan matematika yang diberikan. Kesulitan belajar matematika siswa dalam menggunakan prinsip indikator tidak dapat menerapkan rumus berada pada tingkat rendah. Ditemukan bahwa siswa yang mengalami kesulitan tersebut adalah siswa yang berkemampuan rendah. Berarti masih diperlukan pembimbingan yang lebih serius kepada siswa yang berkemampuan rendah dengan cara pembimbingan langsung oleh guru dan melalui tutor sebaya. Sehingga siswa yang berkemampuan rendah dapat ditingkatkan kemampuannya.

\section{DAFTAR PUSTAKA}

Apriliawan, A., Gembong, S., \& Sanusi, S. (2013). Analisis Kesalahan Penyelesaian Soal Uraian Matematika Siswa MTs pada Pokok Bahasan Unsur-Unsur Lingkaran. JIPM (Jurnal Ilmiah Pendidikan Matematika), 1(2). https://doi.org/10.25273/jipm.v1i2.480

Ardi, Z., Rangka, I. B., Ifdil, I., Suranata, K., Azhar, Z., Daharnis, D., Afdal, A., \& Alizamar, A. (2019). Exploring the Elementary Students Learning Difficulties Risks on Mathematics Based on Students Mathematic Anxiety, Mathematics Self-Efficacy and Value Beliefs Using Rasch Measurement. Journal of Physics: Conference Series, 1157(3), 032095. https://doi.org/10.1088/1742-6596/1157/3/032095

Dangnga, M., \& Muis, A. (2015). Teori Belajar dan Pembelajaran Inovatif. https://scholar.google.com/scholar?cluster=16827700042778377319\&hl=en\&oi=scholarr

Fritz, A., Haase, V. G., \& Räsänen, P. (2019). International Handbook of Mathematical Learning Difficulties: From the Laboratory to the Classroom. In International Handbook of Mathematical Learning Difficulties: From the Laboratory to the Classroom. Springer International Publishing. https://doi.org/10.1007/978-3-319-97148-3

Hapizah. (2017). Kemampuan Mahasiswa Menyelesaikan Soal Problem-Solving Mata Pelajaran Matematika Tingkat Sekolah Menengah Pertama. Jurnal Pendidikan dan Pembelajaran (JPP), 23(2), 124-131. http://journal.um.ac.id/index.php/pendidikan-danpembelajaran/article/view/10163

Hasibuan, E. K. (2018). Analisis Kesulitan Belajar Matematika Siswa pada Pokok Bahasan Bangun Ruang Sisi Datar di SMP Negeri 12 Bandung. AXIOM: Jurnal Pendidikan dan Matematika, 7(1). https://doi.org/10.30821/axiom.v7i1.1766 
Hasratuddin. (2014). Pembelajaran Matematika Sekarang dan yang akan Datang Berbasis Karakter. Jurnal Didaktik Matematika, 1(2). http://www.e-repository.unsyiah.ac.id/DM/article/view/2075

Jamal, F. (2014). Analisis Kesulitan Belajar Siswa dalam Mata Pelajaran Matematika pada Materi Peluang Kelas XI IPA SMA. In Jurnal Pendidikan Matematika) (Vol. 1, Issue 1). https://www.ejournal.stkipbbm.ac.id/index.php/mtk/article/view/232

Kusumaningrum, D. S., Arum, S., \& Lestari, P. (2019). Analisis Kesulitan Belajar Matematika Diskrit Mahasiswa Teknik Informatika. In PRISMA (Vol. 8, Issue 2). https://doi.org/10.35194/JP.V8I2.717

Pramesti, C. (2019). Analisis Kemampuan Kognitif Mahasiswa pada Mata Kuliah Teori Bilangan. Cakrawala Pendidikan, 23.

Sidik, G. S., \& Wakih, A. A. (2020). Kesulitan Belajar Matematika Siswa Sekolah Dasar pada Operasi Hitung Bilangan Bulat. NATURALISTIC: Jurnal Kajian Penelitian Pendidikan dan Pembelajaran, 4(1), 461-470. https://doi.org/10.35568/naturalistic.v4i1.633

Surya, E., \& Novriani, M. R. (2017). Analysis of Student Difficulties in Mathematics Problem Solving Ability at MTS SWASTA IRA Medan Comprarison of Mathematics Learning Outcome Student Thaught Using Guided Discovery with Problem Based Learning (PBL) In X Class of Senior High School MAS Nurul. International Journal of Sciences: Basic and Applied Research, 33(3), 63-75. http://gssrr.org/index.php?journal=JournalOfBasicAndApplied

Suryabrata, S. (2013). Metodologi Penelitian. PT Raja Grafindo Persada.

Syarifah, D. H. H., \& Richanatus. (2017). Studi Kasus Kesulitan Belajar Matematika pada Remaja. Jurnal Psikologi, 11(1). https://ejournal.up45.ac.id/index.php/psikologi/article/view/109

Wang, G., Du, H., \& Liu, Y. (2009). Case Study on Improving High School Students with Learning Difficulties in Mathematics. In Journal of Mathematics Education (C) Education for All (Vol. 2, Issue 2).

Yusmin, E. (2017). Kesulitan Belajar Siswa pada Pelajaran Matematika (Rangkuman dengan Pendekatan Meta-Ethnography). In Jurnal Visi Ilmu Pendidikan (Vol. 9, Issue 1). https://jurnal.untan.ac.id/index.php/jvip/article/view/24806 